\title{
Penguatan Kemampuan Manajerial Kelompok Tani Melalui Pelatihan Laporan Keuangan Usahatani di Sungai Beduk Kota Batam
}

\author{
Sri Ariani Safitri ${ }^{1^{*}}$, Jazuli ${ }^{2}$, Diamon Sembiring ${ }^{3}$, Lutfi Erwin Lubis ${ }^{4}$ \\ ${ }^{1,4}$ Program Studi Akuntansi \\ ${ }^{2,3}$ Program Studi Manajemen \\ 1,2,3,4 Sekolah Tinggi Ilmu Ekonomi Nagoya Indonesia, Komplek Widya Genta \\ Belakang No 1 Kibing, Kec. Batu Aji, Kota Batam, Kepulauan Riau 29424 \\ *e-mail : sri.ariani.sp@gmail.com
}

Informasi Artikel

Diterima Redaksi : 16 Desember 2020

Revisi Akhir : 4 Januari 2021

Diterbitkan Online : 28 Januari 2021

Kata Kunci:

Kelompok Tani, Laporan Keuangan, Pelatihan

\section{PENDAHULUAN}

Sektor pertanian merupakan sektor penyumbang PDB yang cukup besar bagi perekonomian nasional. Namun pada tahun 2019 sumbangan sektor pertanian terhadap PDB Nasional mengalami penurunan dari 10.27 persen turun menjadi 9.41 persen (Kementrian Pertanian, 2020).

Berdasarkan Rencana Strategi Kementrian Pertanian 2020-2024, salah satu yang menjadi permasalahan yakni lemahnya sistem administrasi dan laporan keuangan pada pelaku usahatani sehingga sulit untuk mendapatkan pembiayaan. Lembaga keuangan berpedoman pada laporan keuangan usahatani untuk melihat kelayakan usahatani, sehingga untuk pengajuan kredit atau pinjaman dilembaga keuangan laporan keuangan menjadi salah satu syarat utama (Nugroho dkk, 2017). Hasil penelitian (Kusuma dan Wiryanto, 2019) menunjukkan bahwa kurangnya pengetahuan akan akuntansi dan keuangan menjadi penghambat untuk mendapatkan akses permodalan dari perbankan.

Program Pengabdian Kepada Masyarakat (PKM) dilaksanakan di Desa Mangsang, Sungai Beduk Kota Batam
Abstrak

Kelompok Tani Sei Beduk Kota Batam belum melakukan pencatatan usahatani secara sederhana. Kegiatan pengabdian bertujuan untuk meningkatkan pengetahuan dan keterampilan petani dalam melakukan laporan keuangan sederhana. Metode yang digunakan berupa pelatihan dengan materi berupa contoh pembuatan laporan keuangan. Partisipasi peserta dinilai sangat baik yang ditunjukkan dengan keaktifan petani dalam melakukan diskusi. Kegiatan pelatihan menunjukkan petani sudah mulai mengerti mengenai laporan keuangan sederhana dan akan menerapkannya dalam kegiatan usahatani.

Provinsi Kepulauan Riau. Di Desa Mangsang, mayoritas petani menanam komoditas jagung manis, sayur-sayuran seperti kangkung, bayam dan singkong. Sebagian petani melakukan sistem pertanian tumpang sari yakni menanam lebih dari satu jenis komoditi dilahan garapan yang sama. Namun, ada juga petani yang hanya mengusahakan satu jenis komoditi saja dan mengganti komoditi lain pada musim tanam berikutnya.

Namun selama ini petani tidak mengetahui pasti berapa keuntungan setiap komoditi disetiap musim panen. Sehingga sulit bagi petani untuk menentukan komoditi mana yang paling menguntungkan. Penting bagi petani di Desa Mangsang untuk melakukan laporan keuangan sederhana pada usahatani, sehingga petani dapat mengetahui keuntungan dari setiap komoditas dan menjadi dasar untuk membuat keputusan dalam menentukan komoditas usahatani yang dilakukan. Selain itu, adanya administrasi pencatatan usaha tani akan memudahkan petani untuk mengusulkan proposal usahatani untuk mendapatkan 
pembiayaan dari lembaga keuangan

(Wulandari dkk, 2017).

Berdasarkan hal tersebut, maka hal ini yang menjadikan salah satu pertimbangan untuk melaksanakan Program Pengabdian Kepada Masyarakat (PKM) untuk penguatan kemampuan manajerial kelompok tani melalui pelatihan laporan keuangan usahatani di Sungai Beduk Kota Batam, Provinsi Kepulauan Riau.

\section{METODE}

Adapun uraian metode pelaksanaan adalah dengan metode lesson study yang pelaksanaannya sama dengan penelitian tindakan kelas dengan tiga tahapan:

\section{a) Tahap I : Perencanaan (Planning)}

Perencanaan dimulai dengan

komunikasi dan koordinasi dengan pihak mitra yaitu ketua Kelompok Tani wilayah sei beduk, kami akan memaparkan rencana pelaksanaan program pengabdian kepada masyarakat ini sekaligus mengkoordinasikan waktu dan tempat pelaksanaan, metode pelatihan, jumlah peserta, bahan-bahan dan peralatan yang dibutuhkan. Hal ini dilakukan sampai semua aspek sudah benar-benar siap sampai tahap pelaksanaan sehingga tidak ada lagi penghalang-penghalang atau hambatan yang berhubungan dengan persiapan. Pada tahap ini diharapkan juga sudah ada koordinasi yang baik antara tim dengan mitra.

b) Tahap II : Pelaksanaan

Tahap ini dibagi menjadi beberapa kegiatan:

- Pemaparan: pada saat pemaparan, tim akan memaparkan hal-hal umum mengenai proses administrasi dalam pengusulan kelompok tani di dinas pertanian kota Batam serta kemampuan manajerial dan tata kelola keuangan.

- Pelatihan: Pelatihan ini diharapkan akan memberi pengetahuan dan dapat diimplementasikan oleh para kelompok tani sehingga nantinya dapat meningkatkan daya saing bagi para pelaku kelompok tani di lingkungan wilayah sungai beduk.
Peserta pelatihan merupakan anggota kelompok tani di Desa Mangsang Kecamatan Sei Beduk Kota Batam. Lokasi PKM dari mitra PKM sekitar 15 Kilometer.

\section{HASIL DAN PEMBAHASAN}

Dalam pelaksanaan pelatihan ini, peserta yang terdiri dari para petani yang merupakan anggota dari gabungan kelompok tani wilayah Sungai Beduk Kota Batam yang berjumlah 24 petani. Adapun kelompok tani yang hadir berasal dari enam kelompok tani, yakni kelompok tani maju sejahtera, kelompok tani tower indah, kelompok tani jaya makmur abadi, kelompok tani ladang berkah, kelompok tani marga jaya dan kelompok tani jaya makmur.

Sebelum peserta pelatihan dipersilahkan duduk, peserta diberikan masker sebagai bentuk kepedulian untuk menjaga kesehatan. Materi yang diberikan pada kegiatan pelatihan ini yaitu aktivitasaktivitas apa saja yang perlu dicatat dalam kegiatan usahatani, berapa banyak inputinput produksi yang dipergunakan untuk usahataninya setiap musim panen dan juga berapa biaya yang telah dikeluarkan terkait dengan aktivitas-aktivitas yang telah dijalankan oleh para petani dalam kegiatan operasional usahatani.

Kegiatan Pengabdian Masyarakat (PKM) menyampaikan dua materi, yang pertama yakni pelatihan manajerial petani yang disampaikan dengan pemaparan dan diskusi. Materi kedua yakni peserta pelatihan diberikan modul pelatihan untuk menyusun laporan keuangan usahatani secara sederhana dan diuraikan secara ringkas dan rinci beserta manfaat dan cara penerapannya.

Para peserta Kegiatan Pengabdian Masyarakat (PKM) yakni petani, sebelumnya kurang mengetahui bagaimana membuat laporan keuangan sederhana dan tidak melakukan pencatatan dalam setiap kegiatan usahatani. Selama ini petani hanya mengingat saja setiap biaya yang dikeluarkan dan berapa hasil panen yang diperoleh.

Partisipasi masyarakat dalam pelaksanaan program Kegiatan Pengabdian Masyarakat (PKM) dinilai berdasarkan 
tingkat kehadiran, keaktifan dalam berdiskusi dan keinginan untuk mengimplementasikan program ini. Partisipasi para petani dinilai aktif dan antusias dalam kegiatan diskusi dalam KegiatanPengabdian Masyarakat (PKM) ini, hal ini ditunjukkan dengan keinginan petani untuk didampingi menyusun laporan keuangan dan semangat untuk mengimplementasikannya.

Pada Tabel. 1 contoh laporan keuangan sederhana yang digunakan para petani untuk diterapkan pada pencatatan usahatani.

Tabel 1. Contoh Pembukuan Sederhana Usahatani Jagung Per Musim Tanam Per $\mathrm{Ha}$

\begin{tabular}{cllccc}
\hline Tanggal & Keterangan & Satuan & $\begin{array}{c}\text { Pemasukan } \\
\text { (Rp) }\end{array}$ & Pengeluaran & $\begin{array}{c}\text { Saldo } \\
\text { Akhir }\end{array}$ \\
\hline $1 / 8 / 20$ & Saldo Awal & & & & 5.000 .000 \\
$2 / 8 / 20$ & Biaya Benih & $25 \mathrm{Kg}$ & & 500.000 & 4.500 .000 \\
$3 / 8 / 20$ & Biaya & $200 \mathrm{Kg}$ & & 500.000 & 4.000 .000 \\
& Pupuk Urea & & & & \\
$4 / 8 / 20$ & Biaya & $200 \mathrm{Kg}$ & & 500.000 & 3.500 .000 \\
& Pupuk NPK & & & 500.000 & 2.500 .000 \\
$5 / 8 / 20$ & Biaya & $1 \mathrm{~L}$ & & & \\
& Pestisida & & & 500.000 & 2.000 .000 \\
$5 / 8 / 20$ & Biaya lain- & & & & 7.000 .000 \\
& lain & & & \\
$1 / 11 / 20$ & Produksi & $500 \mathrm{Kg}$ & 5.000 .000 & & \\
& Jagung & & & & \\
& Harga & Rp & & & \\
& Jagung $/ \mathrm{Kg}$ & 10.000 & & &
\end{tabular}

Dari contoh laporan keuangan tersebut, selanjutnya menghitung pendapatan petani, total biaya-biaya dan keuntungan petani per musim tanam.

Pendapatan = Hasil Panen $(\mathrm{Kg}) \times$ Harga Jagung $/ \mathrm{Kg}$

$500 \mathrm{Kg} \times \operatorname{Rp} 10.000=\operatorname{Rp} 5.000 .000$

Total Seluruh Biaya yang dikeluarkan= Rp 2.500.000

Keuntungan = Pendapatan - Total Biaya

$\operatorname{Rp} 5.000 .000-\operatorname{Rp} 2.500 .000=\operatorname{Rp} 2.500 .000$

Mayoritas petani di wilayah Sungai Beduk, memilih komoditas jagung untuk diusahakan. Namun sebagian petani ada juga yang menggunakan sistem tumpang sari, jagung, ubi kayu dan sayur-sayuran seperti kangkung atau bayam.

Para peserta Kegiatan Pengabdian Masyarakat (PKM) yakni petani, sebelumnya kurang mengetahui bagaimana membuat laporan keuangan sederhana dan tidak melakukan pencatatan dalam setiap kegiatan usahatani. Selama ini petani hanya mengingat saja setiap biaya yang dikeluarkan dan berapa hasil panen yang diperoleh. Setelah dilakukan pelatihan dan pendampingan, hasil yang diperoleh masyarakat mulai memahami apa yang disebut dengan pencatatan usaha beserta manfaat pencatatan.

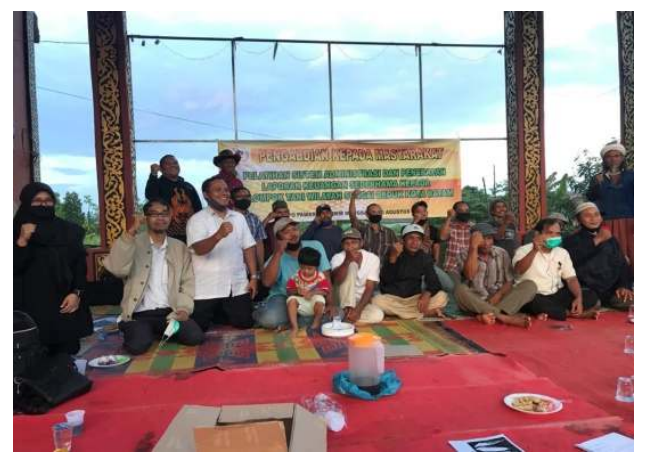

Gambar 1. Foto bersama dengan peserta pelatihan

\section{KESIMPULAN}

Kegiatan pengabdian kepada masyarakat (PKM) ini memiliki tujuan untuk meningkatkan kesadaran petani akan pentingnya administrasi pencatatan usaha tani, meningkatkan pengetahuan dan keterampilan petani dalam penyusunan administrasi usaha tani, yang dimulai dari rencana anggaran, pencatatan dan analisa sederhana, dan meningkatkan jiwa manajerial petani dalam mengelola usaha tani.

Kegiatan Pengabdian Kepada Masyarakat (PKM) dilaksanakan di Desa Mangsang Wilayah Sungai Beduk Kota Batam. Metode pelaksanaan yang digunakan adalah pelatihan dan pendampingan pencatatan keuangan usaha tani dengan menggunakan laporan keuangan sederhana.

Setelah dilakukan pelatihan dan pendampingan, hasil yang diperoleh masyarakat mulai memahami apa yang disebut dengan pencatatan usaha beserta manfaat pencatatan. Untuk musim tanam selanjutnya, petani akan menerapkan pencatatan usahataninya dengan menggunakan laporan keuangan sederhana yang telah disampaikan.

\section{SARAN}


Setelah kegiatan pelatihan, sebaiknya untuk selanjutnya dilakukan pendampingan dan monitoring kegiatan pencatatan usaha tani. Dalam kegiatan monitoring, dapat diketahui bahwa petani sudah mulai mengerti mengenai pencatatan usaha tani dan telah menerapkannya.

\section{UCAPAN TERIMA KASIH}

Puji Syukur kepada Allah SWT atas selesainya kegiatan pengabdian kepada masyarakat ini. Kami juga mengucapkan terimakasih kepada pihak-pihak yang telah membantu kegiatan PKM ini, yakni Ketua STIE Nagoya Indonesia, Ketua Program Studi Akuntansi STIE Nagoya Indonesia, Para Dosen STIE Nagoya Indonesia, dan Kelompok Tani Desa Mangsang Kecamatan Sei Beduk Kota Batam. Semoga Kegiatan PKM ini bermanfaat bagi kita semua khususnya bagi para petani di Kota Batam.

\section{REFERENSI}

[1] Kementrian Pertanian, 2020, Rencana Strategi Kementrian Pertanian 20202024, Kementrian Pertanian Republik Indonesia, Jakarta.

[2] Nugroho, A., Sari, P., Suratoyah, K. dan Pratiwi, L. Farm. 2017. Recording Kelompok Tani Timbul Karya Kecamatan Paliyan, Kabupaten Gunungkidul Yogyakarta. Indonesian Journal of Community Engagement, Vol. 2, No. 2, pp. 205-215.

[3] Kusuma dan Wiryanto. 2019. Pemberdayaan Masyarakat Berbasis Penyusunan Laporan Keuangan Sederhana Pada Kelompok Usaha Tani Pembibitan Tanaman Buah. Jurnal Qardhul Hasan, Vol. 5, No. 1, pp. 2550-1143.

[4] Wulandari, E., Endah, dan Supiyandi, D. Penguatan Kemampuan Manajerial Petani Melalui Pelatihan dan Pendampingan Pencatatan Finansial Usaha Tani Di Kabupaten Cianjur. Jurnal Aplikasi Ipteks untuk Masyarakat, Vol. 6, No. 3, pp. 189192. 